\title{
Teaching and Learning School Informatics: A Concept-Based Pedagogical Approach
}

\author{
Said HADJERROUIT \\ Faculty of Technology and Sciences, University of Agder \\ Serviceboks 422, N-4604 Kristiansand, Norway \\ e-mail: said.hadjerrouit@uia.no
}

Received: April 2009

\begin{abstract}
While informatics is a well-established discipline in higher education around the world, it is not the case in secondary education, with the exception of a few countries. Generally, what is taught is not informatics as a subject with its own methods, concepts, and principles, but some software tools with the goal that the use is sufficient for students to acquire skills. In addition, an analysis of the current situation reveals that the real competencies of teachers and students in informatics are far weaker than might be expected in secondary education. This work proposes a concept-based pedagogical approach to school informatics. The aim is to provide the students with a more thorough understanding of informatics as a school subject. The work also explores students' views on the contribution of the pedagogical approach and the implications for the teaching and learning of school informatics in secondary schools.
\end{abstract}

Keywords: concept-based pedagogical approach, conceptualization, IT education, learning theory, school informatics.

\section{Introduction}

Despite the ongoing debate about IT education, informatics as a school subject has no real importance in the discussions, because the debate focuses very often on IT as a tool for the learning of other subjects. However, an analysis of the current situation in IT education reveals that there is a need for a subject that goes beyond the strict use of IT as a tool. The establishment of school informatics as a subject in its own right is a challenge for many reasons. Firstly, informatics as a school subject is a young discipline (Woollard, 2005). It lacks a solid tradition of research, in contrast to classical subjects such as mathematics or science education. The fact that there is much less published research work on the pedagogy of school informatics has huge consequences for the teaching and learning of the subject. As a result, there still persist strong disagreements about the nature of school informatics, its aims, content, teaching and learning methods, and assessment approaches (Hammond, 2004). Secondly, school informatics is confronted with the problem of competencies of teachers and students. These are often very low or far weaker than might be expected in secondary education (Bruillard, 2004; Micheuz, 2008). The lack of competencies has significant impacts on student learning, because current teaching methods do 
not provide understanding of informatics on a deeper level than memorizing details of the software, reproducing information about buttons, menu commands, and dialogue boxes (Hadjerrouit, 2008). Moreover, the nature of software systems has changed drastically the last few years. Their mastery requires educated teachers and students with a set of new skills that go beyond the framework of using IT as a tool.

This paper argues for a concept-based pedagogical approach to teaching and learning school informatics. The approach is supposed to provide the students with a more thorough understanding of informatics as a school subject. To assess the value of the approach, this paper investigates the students' perceptions of the approach in classroom and the implications for the teaching and learning of school informatics.

The remainder of this article is structured as follows. First, the paper describes the research goals and questions. Second, the paper gives an overview of the current state of school informatics. Third, the article outlines the underlying theoretical framework of the concept-based pedagogical approach. The next section specifies the evaluation methods, followed by the evaluation findings. Then, the article presents a discussion of the findings. Finally, some remarks on further work conclude the paper.

\section{Research Goals and Questions}

This work examines the students' views on the contribution of a concept-based pedagogical approach to learning school informatics. The investigation is situated within teacher education and an established research partnership between the university and four local secondary schools. Before exploring the pedagogical approach, the current state of research in the field is critically reviewed. Drawing on the implementation of the approach and students' views the work also examines the implications for the teaching and learning of school informatics. Accordingly, this work has four major research goals:

1. To critically review the current state of research with the aim of understanding the problems associated with current teaching and learning of school informatics.

2. To design a concept-based pedagogical approach that takes into consideration the teaching and learning problems associated with school informatics.

3. To implement the approach in four secondary schools and to report on students' views on the contribution of the approach to learning school informatics.

4. To discuss the implications of the approach for the teaching and learning of school informatics in secondary education.

Hence, to explore the pedagogical value of the approach and its implications for school informatics, this work examined the following research questions:

1. How do students perceive the concept-based pedagogical approach in their learning of school informatics?

2. What are the implications for the teaching and learning of school informatics in secondary education? 


\section{Current State of School Informatics}

Informatics is still not really embedded as a compulsory subject in the secondary school scheme of work around the world (ACM, 2003; UNESCO, 2002). The subject is offered as an option among others, and it is mainly seen as a tool that can be used in other subjects. Informatics as a non-compulsory school subject in the New National Curriculum in Norway (2006) is divided into Information Technology I and II. Information Technology I includes four topics: Digital equipment, programming, multimedia applications, and Web development I. Information Technology II includes three topics: Information systems design, databases, and Web development II. However, despite the emphasis on a set of well-defined topics, the Curriculum makes few suggestions as to which methods are required to teach these topics.

Besides the methodological issue, the research literature reveals that school informatics is still confronted with a number of problems. Firstly, informatics is still taught as if this subject is just a tool. As a result, informatics teaching does not provide understanding on a deeper conceptual level than memorizing details of the software, reproducing information about buttons, menu commands, and dialogue boxes (Dagdilelis et al., 2004). Secondly, informatics teaching in secondary schools shows that most students learn by approximations and imitations, reproduction of information, and not by conceptual understanding. On the other hand, existing research confirms that students know a lot about information technologies, but they do not possess a conceptual framework to organize them (Haberman, 2004; Nishida et al., 2009). They lack fundamental ideas, principles, and concepts that may help them to analyze and structure the information (Schwill, 1997; Stechert, 2008; Woollard, 2005). Because students do not possess a conceptual and consistent picture on what is going on in the computer, their activities often rely on what is visible on the screen and interface elements. As a result, when students are confronted with unexpected results, they do not know what they can do to deal with the information that the computer shows on the screen (Bruillard, 2004). Very often, they try a number of options offered by buttons, menu commands, and dialogue boxes. They operate on visible elements, and not on hidden schemes of the information processing, because they cannot understand them.

Several reasons can explain this situation. First, schools adapt slowly to technological and pedagogical changes, and teachers are often reluctant to abandon their pedagogy and their ways of teaching informatics or IT-based subjects (Belland, 2009; Minaidi and Hlapanis, 2005). As a result, teaching methods based on traditional epistemologies are still dominant despite the fact that informatics as a school subject requires a new pedagogy that goes largely beyond the use of IT as a tool.

Second, research reveals that the real competencies and qualifications of teachers in informatics are far weaker than might be expected in secondary education (Bruillard, 2004; Micheuz, 2008). They lack specific knowledge in informatics that goes beyond the use of IT as a tool for the learning of other subjects.

Third, while knowledge about the functionality of software is necessary for teaching informatics, it is impossible for teachers to know all the specific features of all the software tools that they use, because software is continually being developed (Webb, 2002). 
To learn to use software is a complex task that requires more conceptual understanding than just memorizing, approximation, and interaction with the computer.

Fourth, teaching resources and textbooks in informatics are still based on behaviorist pedagogies and epistemologies. Textbooks are full of pictures and screens, indicating step by step what students need to do (Bruillard, 2004). Deep learning is not necessary in order to follow the steps, since conceptualizations are not required.

Fifth, there is little published research work on school informatics regarding content, modalities of teaching and learning, didactical and pedagogical issues of the field. As a result, school informatics lacks an extensive research base of materials like the one published for mathematics (Hammond, 2004; Hromkovic, 2006). The lack of research is clearly an obstacle for improving the teaching and learning of school informatics.

Another reason is the WISIWYG philosophy of current user interfaces and associated metaphors such as the book metaphor. These rely on what is visible on the screen, and as a result, students cannot make conceptualizations about the invisible part of the software (Bruillard, 2004; Freischlad and Stechert, 2008). Consequently, they cannot develop conceptual representations of the information processing. The reason is that most of the details of the information processing are hidden behind the graphical user interface.

Finally, a number of informatics topics are more difficult to teach than other subjects, because they require a much greater range of professional and pedagogical skills than those required to teach a unit of work within a specific subject area (McDougall and Boyle, 2004). As a result, it is often difficult for teachers to identify suitable contexts of software use to develop informatics concepts.

Given this situation, teachers need a new vision of informatics that goes beyond the use of IT as a tool. A new approach to informatics should rely on learning theories, conceptualizations, and pedagogical principles rather than imitation, approximation, memorizing, and interaction with the computer. A new vision of informatics would help teachers and students to successfully exploit the potential capabilities of information technologies. To achieve this, schools must give more consideration to new pedagogies that are more suited to informatics as a school subject.

\section{Theoretical Framework}

The design of a concept-based pedagogical approach to school informatics depends on the chosen theoretical framework. The framework specifies teaching and learning processes in a dialectical relationship. The framework helps teachers to bridge the gap between informatics concepts and the student, on the one hand. It provides support for the student to understand the subject matter and grasp the meaning of informatics concepts, on the other hand. Hence, the theoretical framework has two major components:

1. Teaching processes that set up learning activities and help students to engage in conceptual learning.

2. Learning processes that are tightly connected to the teaching processes in a reciprocal relationship. 


\subsection{Teaching Processes}

Traditionally, teaching informatics involves two major steps. First, the teacher gives an overview of the software functionality, and demonstrates how the following problem should be solved using a step-by-step procedure based on visible elements of the computer such as screen shots, dialogue boxes, and menu commands. Then, the student tries to solve the problem by using this procedure. Of course, it is possible to begin with the problem, and then explain the software functions to be used. Nevertheless, according to Hadjerrouit (2008), there are three basic problems related to this form of teaching:

1. The memory problem, because it is difficult for the student to remember the procedure.

2. The understanding problem, since it cannot be expected that the student has understood how to use the software functionality to solve the problem.

3. The dependence problem, because the student is not able to work on his own solving the problem.

Clearly, the ability to make use of software tools for problem solving requires more than remembering dialogue boxes, finding details associated with the software, interacting with the computer, operating on visible interface elements, and finding the right sequence of commands. Techniques, such as teaching small groups, breaking down the lessons into smaller parts, providing the students with detailed manuals showing how the problem should be solved step-by-step, using textbooks, or adopting similar methods, do not solve the basic problems of traditional teaching.

However, as Webb (2002) argued, it is important for teachers not to be overwhelmed by trying to master all the details of the software but to focus on the main features of types of software and how to find information about the detailed techniques. Using software tools for solving informatics problems requires the acquisition of a number of higherorder thinking skills such as understanding the software functions and their relationships, understanding informatics concepts, developing operative representations, understanding the invisible parts of the information processing, creating associations in the language used, and transferring previously acquired skills to the problem to be solved.

In line with these considerations, this work proposes a teaching approach associated with a number of pedagogical principles (Hadjerrouit, 2008; Herskin, 2004). First, an important objective is to remove the software details needed to be remembered, using a problem-oriented understanding process, and changing the focus from approximation, imitation, and memorization to conceptual understanding. For this purpose, a pedagogical strategy with three major phases is proposed:

a) presentation phase (or overview phase),

b) exercise phase (or problem phase),

c) summary phase.

The very basis of the teaching strategy is the presentation phase. The objective of this phase is to generate conceptual understanding using "understanding tools". These could be situated examples and visualizations. By using situated examples, the teacher should enable the students to understand the problem. The principles and concepts are 
then explained through visualizations. Finally, the teacher gives a procedure overview using visual boxes showing the main steps of the problem solving process. This is what is called the three P's. Accordingly, the presentation phase has three components: The Problem, the Principles, and the Procedural overview.

Then, before the students solve the problem or exercise, an instruction sheet for this type of exercise is handed out. It should give a generalized explanation on how to solve this type of exercise. The fundamental idea behind the instruction sheet is to provide the student with a brief manual. The aim is to enable the student to become less dependent on the teacher's assistance. The instruction sheet should not contain any screen shots. It should help the student pay attention to information in menus and dialogue boxes of the software tool. An important principle is not to mix the exercise and the instruction sheet. The instruction sheet is divided into three columns:

- column 1 gives a procedural overview (heading: "Phase");

- column 2 explains why the student should perform this step (heading: "Explanation");

- column 3 leads the student to the correct menu, buttons, and dialogue boxes (heading: "Interaction").

A segment of an instruction sheet for designing a form using the Microsoft database Access is shown in Table 1.

In the summary phase, students get the opportunity to raise questions regarding the specific exercise or more general problems associated with conceptual understanding.

Table 1

A segment of an instruction sheet for designing a form using the database Access

\begin{tabular}{|c|c|c|}
\hline Phase & Explanation & Interaction \\
\hline$\checkmark$ DESIGN FORM & $\begin{array}{l}\text { Design a form based on a } \\
\text { template. Each form } \\
\text { should have Iilmited tasks. }\end{array}$ & 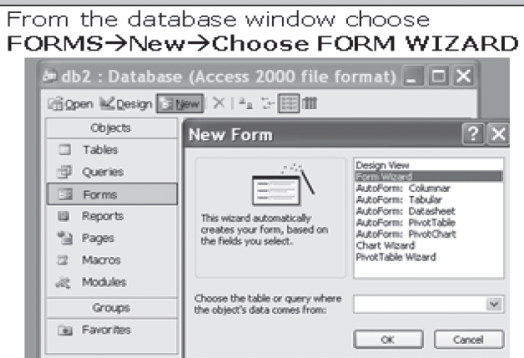 \\
\hline $\begin{array}{l}\text { CHOOSE DATA } \\
\text { SOURCE }\end{array}$ & $\begin{array}{l}\text { Choose tables or queries } \\
\text { which contain the desired } \\
\text { data. }\end{array}$ & $\begin{array}{l}\text { Choose the table or query from the list. } \\
\text { Click OK. }\end{array}$ \\
\hline $\begin{array}{l}\text { CHOOSE } \\
\text { CONTENT FIELDS }\end{array}$ & $\begin{array}{l}\text { Choose fields in the form. } \\
\text { Do not choose a field } \\
\text { many times }\end{array}$ & $\begin{array}{l}\text { Mark the field name. } \\
\text { Click }>\text { for simple field } \\
\text { Click }>>\text { for all fields. } \\
\text { Click NEXT. }\end{array}$ \\
\hline
\end{tabular}


The teacher can then provide supplementary information. In this phase the students might also discuss how the informatics concepts could be used or re-used in similar situations.

\subsection{Learning Processes}

Teaching processes should provide students with learning opportunities at three different levels: At the presentation level, exercise level, and summary level. First, the presentation level aims at providing students with conceptual understanding by means of the three P's (Problem, Procedure, and Principle) and understanding tools such as situated examples and visualizations. Students learn informatics concepts through an adequate combination of these elements. There are many informatics concepts that students can learn in secondary education, for example the concept of model, algorithm, information, data, structure, system, process, program, Web template, client-server architecture, usability, etc. In addition, the concept of form is important because it is widely used in relation to Web-based systems and databases in secondary schools.

Conceptual understanding of informatics fits well with the cognitive learning theory, which emphasizes the learner's schema as an organized knowledge structure (Bruner, 1990; Gagne et al., 1993). When teachers apply a cognitive approach at the presentation level, they focus on the understanding of concepts and their relationships. More specifically, teachers use understanding tools for teaching informatics concepts, among them situated examples for describing the problem, visualizations for explaining the concepts and principles, and procedure overview for showing the main steps of the problem solving process. If students are able to understand the connections between the concepts, break down information, and rebuild it with logical connections, then their understanding of informatics concepts will increase.

Second, learning at the exercise level is assumed to occur as students interact individually with the problem to be solved, the software tool, and instruction sheets. This fits well with the constructivist learning theory, which views knowledge as a constructed entity made by each and every learner through a learning process (Duffy et al., 1993; Piaget, 1972; Steffe and Gale, 1995). Constructivist learning requires students to demonstrate their skills by constructing their own knowledge when solving authentic problems. The aim is to enable each student to work at his/her own pace, and from his/her prerequisites. The teacher works as a mentor of learning, not as a transmitter of knowledge. The fundamental idea behind the concept of instruction sheet also fits well with constructivist learning. Instruction sheets enable students to become less dependent on the teacher, help to explore the problem, and construct a solution.

Third, in the summary phase, students get the opportunity to raise questions regarding the specific exercise and the concepts they are supposed to learn. At this level, learning occurs as students improve and reflect on their concept understanding through discussion and collaboration with the teacher and fellow students. This fits well with the socially situated learning theory (Vygotsky, 1978; Wenger, 1998). Collaborative learning can be extended to the exercise phase, because it can be useful to let the students work together in this phase. This will increase the learning by collaboration in a higher degree, and will allow the student to engage in levels of activity that could not be managed alone. 
Hence, the underlying idea of the learning processes at the presentation, exercise, and summary level is a suitable blend of learning theories (Karagiorgi and Symeou, 2005; Lin and Hsieh, 2001). This fits well with the three-stage model or learning cycle, proposed by Mayes and Fowler (1999), in which they identified three types of learning - conceptualization, construction, and dialogue. The essential characteristic of the learning cycle is that it describes a continuous cycle of gradual refinement of understanding. Accordingly, learning develops in three phases, beginning with conceptualization, progressing through construction to dialogue. Conceptualization is characterized by the process of interaction between the students' pre-existing framework and teacher's knowledge. The construction phase refers to the process of building concepts through their use in the performance of meaningful tasks. The dialogue phase refers to the testing and refinement of conceptualizations during conversation with both fellow students and teachers. Dialogue emerges through collaborative learning.

The three stages of the proposed pedagogical approach include elements that are closely related to the learning cycle. As a result, the three stages of the approach can be re-conceptualized within the learning cycle. The presentation phase is associated with the conceptualization phase as it focuses on conceptual understanding. The exercise phase is related to the construction phase as it aims at the construction of new knowledge and its use in the problem-solving process. The summary phase is related to the dialogue phase as it is concerned with collaboration and discussion. The essential characteristic of the pedagogical approach is that it describes a continuous cycle of gradual understanding. Hence, the conceptualization, construction, and dialogue phase are not separated. They are interdependent and reciprocal. Fig. 1 gives an overview of the concept-based pedagogical approach with respect to the learning cycle and learning theories.

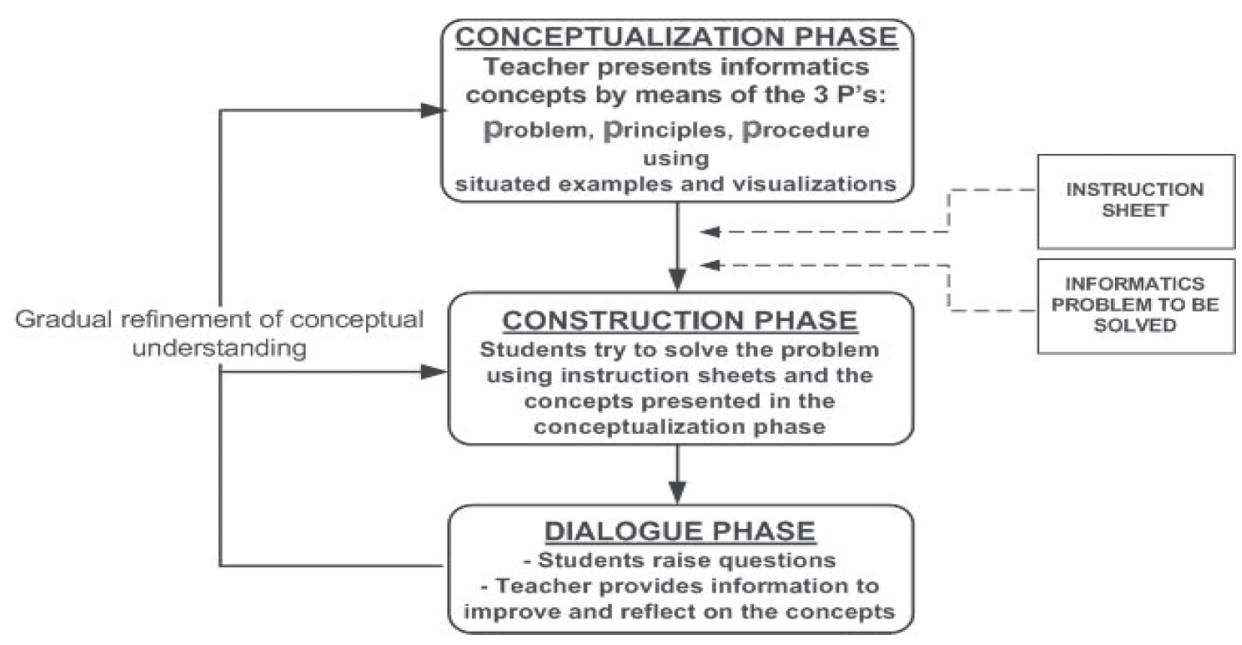

Fig. 1. Concept-based pedagogical approach to school informatics. 


\section{Evaluation Methods}

This work is situated within teacher education at the university level in collaboration with four secondary schools, where teaching practice of six weeks is performed. The unit of study is the learning of informatics as a school subject using the concept-based pedagogical approach. The goal of this work was twofold. First, analyze the students' perceptions of the pedagogical approach. Second, identify the implications for the teaching and learning of school informatics in secondary schools.

\subsection{Survey Questionnaire}

Evaluation data came from a survey questionnaire completed by 99 students between 16-18 years. The questionnaire was delivered to the students at the end of the teaching sessions. To measure the students' responses, a four-point Likert scale from 1 to 4 was used, where 1 was coded as the lowest and 4 as the highest ( 1 = "Learned Very Little"; 2 = "Learned Little"; 3 = "Learned Much"; 4 = "Learned Very Much"). The students were asked to respond by placing a cross " $\mathrm{X}$ " in the appropriate box using the scale provided. The evaluation focused on what the students had to say about the concept-based pedagogical approach. The evaluation criteria across the four schools can be summarized in terms of three major organizing themes:

- perceived learning potentiality of the concept-based pedagogical approach compared to project-based and traditional teaching;

- perceived motivational power of the approach compared to project-based and traditional teaching;

- perceived effect of the approach on student learning when used in classroom.

\subsection{Participating Schools and Students}

Data came from four different secondary schools that participated in this study in 2008 . There was some variation of IT provision among the four schools. School 1, 3, and 4 (from the same town) were highly resourced, providing a high degree of software and hardware infrastructure. School 2 (from another town) was quite well resourced with IT, offering excellent opportunities to computer rooms and modern software. In addition to IT provision, the schools used traditional and/or project-based ways of teaching. Hence, a number of students had some experience with both approaches to teaching.

\subsection{Teaching Subjects}

The following teaching subjects were taught by four different trainee teachers in four different schools. These can be related to four classes according to the four schools. All schools offered informatics as a school subject in one or another form. The context, in which the teaching subjects were taught, is listed in Table 2. Each row refers to the class, the teaching subject, the number of lessons of 45 minutes, and the number of participating students. 
Table 2

Teaching subjects

\begin{tabular}{|c|c|c|c|}
\hline $\begin{array}{l}\text { Class / } \\
\text { School }\end{array}$ & Teaching subjects & $\begin{array}{l}\text { Teaching } \\
\text { duration }\end{array}$ & $\begin{array}{c}\text { Number of } \\
\text { students }\end{array}$ \\
\hline $\begin{array}{l}\text { Class } 1 / \\
\text { School } 1\end{array}$ & $\begin{array}{l}\text { Designing and developing Web shops using } \\
\text { Dreamweaver CS3 and Flash CS3 professional. }\end{array}$ & $2 \times 45 \mathrm{~min}$ & 17 \\
\hline $\begin{array}{l}\text { Class } 2 \text { / } \\
\text { School } 2\end{array}$ & $\begin{array}{l}\text { Designing audio files and formatting sound effects } \\
\text { using the Audacity program. }\end{array}$ & $6 \times 45 \mathrm{~min}$ & 58 \\
\hline $\begin{array}{l}\text { Class } 3 / \\
\text { School } 3\end{array}$ & $\begin{array}{l}\text { Designing and developing Web-based applications } \\
\text { using Adobe Flash CS3 and Adobe Dreamweaver } \\
\text { CS3. }\end{array}$ & $2 \times 45 \mathrm{~min}$ & 16 \\
\hline $\begin{array}{l}\text { Class } 4 \text { / } \\
\text { School } 4\end{array}$ & $\begin{array}{l}\text { Managing and maintaining files using Windows } \\
\text { Server } 2003 \text { and Active Directory. }\end{array}$ & $2 \times 45 \mathrm{~min}$ & 8 \\
\hline
\end{tabular}

\section{Evaluation Findings}

To evaluate the students' perceptions of the concept-based pedagogical approach to school informatics, the same survey questionnaire was used in each class.

\subsection{Students' Perceptions in Class 1}

Table 3 shows the following results in class $1(N=16)$. The majority of the students believed that the learning potentiality of the approach is very high (18.8\%) or high (37.4\%). Likewise, the motivational power is high for $50 \%$ and very high for $12.5 \%$ of the students. However, the score achieved for project-based is higher than the one of the concept-based approach both with regard to learning potentiality and motivational power. Moreover, $62.5 \%$ of the students indicated that they liked traditional teaching.

While $37.6 \%$ of the students felt that the conceptualization phase helped them, which is clearly under the average, $68.7 \%$ believed that instruction sheets were helpful. However, these results must take into account that there is a wider variation in the responses both with regard to the conceptualization phase and instruction sheets. This means that some felt they learned very much, while other learned very little. Moreover, the overwhelming majority of the students (75.0\%) indicated that they learned very much or much when they collaborated with other students, and $81.3 \%$ when they asked their teacher for help. Finally, 56.3\% think that the dialogue phase was successful.

\subsection{Students' Perceptions in Class 2}

Table 4 shows the following results in class $2(N=58)$. Contrary to class $1,53.4 \%$ indicated that the learning potentiality is very high and $37.9 \%$ think it is high. Moreover, the approach is highly motivating for $67.2 \%$ and motivating for $31.0 \%$ of the students. Likewise, Table 4 shows that $12.1 \%$ felt that they learned very much and $72.4 \%$ learned much in the conceptualization phase, in contrast to class 1 . This is also the case for the use of instruction sheets (15.5\% learned very much and $69.0 \%$ learned much). Moreover, 
Table 3

Students' perceptions in class 1 (in percent)

\begin{tabular}{lccccr}
\hline & $N$ & $\begin{array}{c}\text { Learned } \\
\text { very much }\end{array}$ & $\begin{array}{c}\text { Learned } \\
\text { much }\end{array}$ & $\begin{array}{c}\text { Learned } \\
\text { little }\end{array}$ & $\begin{array}{r}\text { Learned } \\
\text { very little }\end{array}$ \\
\hline & $\begin{array}{c}\text { Learning } \\
\text { potentiality }\end{array}$ & & & \\
Traditional approach & 16 & 12.5 & 50.0 & 25.0 & 12.5 \\
Concept-based pedagogical approach & 16 & 18.8 & 37.4 & 25.0 & 18.8 \\
Project-based approach & 16 & 18.8 & 56.2 & 25.0 & 0.0 \\
& Motivational power & & & \\
Traditional approach & 16 & 6.2 & 31.2 & 43.8 & 18.8 \\
Concept-based pedagogical approach & 16 & 12.5 & 50.0 & 25.0 & 12.5 \\
Project-based approach & 16 & 25.0 & 50.0 & 25.0 & 0.0 \\
& \multicolumn{7}{c}{ Learning effect } & of the concept-based approach & & \\
Conceptualization phase (3 P's) & 16 & 18.8 & 18.8 & 31.2 & 31.2 \\
Construction phase: Instruction sheets & 16 & 31.2 & 37.5 & 18.8 & 12.5 \\
Construction phase: Student collaboration & 16 & 31.2 & 43.8 & 25.0 & 0.0 \\
Construction phase: Ask teacher for help & 16 & 12.5 & 68.8 & 12.5 & 6.2 \\
Dialogue phase: Discuss with teacher & 16 & 12.5 & 43.8 & 31.2 & 12.5 \\
\hline
\end{tabular}

Table 4

Students' perceptions in class 2 (in percent)

\begin{tabular}{|c|c|c|c|c|c|}
\hline & $N$ & $\begin{array}{c}\text { Learned } \\
\text { very much }\end{array}$ & $\begin{array}{l}\text { Learned } \\
\text { much }\end{array}$ & $\begin{array}{l}\text { Learned } \\
\text { little }\end{array}$ & $\begin{array}{c}\text { Learned } \\
\text { very little }\end{array}$ \\
\hline \multicolumn{6}{|c|}{ Learning potentiality } \\
\hline Concept-based pedagogical approach & 58 & 53.4 & 37.9 & 6.9 & 1.7 \\
\hline \multicolumn{6}{|c|}{ Motivational power } \\
\hline Concept-based pedagogical approach & 58 & 67.2 & 31.0 & 1.7 & 0.0 \\
\hline \multicolumn{6}{|c|}{ Learning effect of concept-based approach } \\
\hline Conceptualization phase (3 P's) & 58 & 12.1 & 72.4 & 15.5 & 0.0 \\
\hline Construction phase: Instruction sheets & 58 & 15.5 & 69.0 & 10.3 & 5.2 \\
\hline Construction phase: Student collaboration & 58 & 81.0 & 13.8 & 5.2 & 0.0 \\
\hline Construction phase: Ask teacher for help & 58 & 1.7 & 5.2 & 89.7 & 3.4 \\
\hline
\end{tabular}

$81.0 \%$ think that they learned very much and $13.8 \%$ much when they collaborated with other students, in stark contrast to asking their teacher for help $(1.7 \%$ learned very much, $5.2 \%$ learned much, and $89.7 \%$ learned little). 
Table 5

Students' perceptions in class 3 (in percent)

\begin{tabular}{|c|c|c|c|c|c|}
\hline & $N$ & $\begin{array}{c}\text { Learned } \\
\text { very much }\end{array}$ & $\begin{array}{c}\text { Learned } \\
\text { much }\end{array}$ & $\begin{array}{c}\text { Learned } \\
\text { little }\end{array}$ & $\begin{array}{c}\text { Learned } \\
\text { very little }\end{array}$ \\
\hline \multicolumn{6}{|c|}{ Learning potentiality } \\
\hline Traditional approach & 15 & 40.0 & 46.7 & 13.3 & 0.0 \\
\hline Concept-based pedagogical approach & 15 & 20.0 & 60.0 & 13.3 & 6.7 \\
\hline \multicolumn{6}{|c|}{ Motivational power } \\
\hline Traditional approach & 15 & 26.7 & 46.7 & 26.6 & 0.0 \\
\hline Concept-based pedagogical approach & 15 & 26.7 & 60.0 & 6.7 & 6.6 \\
\hline \multicolumn{6}{|c|}{ Learning effect of concept-based approach } \\
\hline Conceptualization phase (3 P's) & 15 & 26.7 & 33.3 & 40.0 & 0.0 \\
\hline Construction phase: Instruction sheets & 15 & 26.7 & 20.0 & 46.7 & 6.6 \\
\hline Construction phase: Student collaboration & 15 & 20.0 & 66.7 & 13.3 & 0.0 \\
\hline Construction phase: Ask teacher for help & 15 & 33.3 & 53.3 & 13.3 & 0.0 \\
\hline
\end{tabular}

\subsection{Students' Perceptions in Class 3}

The evaluation of class $3(N=15)$ shows the following results (Table 5). These indicate that the learning potentiality of the concept-based approach is very high for $20.0 \%$ and high for $60.0 \%$ of the students. Likewise, the results show that the motivational power is very high for $26.7 \%$ and high for $60.0 \%$ of the students. However, it appears that students were still satisfied with traditional teaching both with regard to learning potentiality and motivational power as the results clearly reveal $(86.7 \%$ and $73.4 \%$ respectively).

Furthermore, the results point out that $26.7 \%$ learned very much and $33.3 \%$ learned much when the conceptualization phase was used. The use of instruction sheets was very helpful for $26.7 \%$ and helpful for $20.0 \%$ of the students, which is less than the majority. In contrast to instruction sheets, $20.0 \%$ learned very much and $66.7 \%$ learned much when they collaborated with other students. Likewise, similar results were achieved when students asked their teacher for help (33.3\% learned very much and 53.3\% learned much).

\subsection{Students' Perceptions in Class 4}

In class $4(N=8)$ the teacher did not compare the concept-based approach with traditional and project-based teaching with regard to the learning potentiality and motivational power. Instead, the teacher focused exclusively on the learning effect of the approach when used in classroom. The results are shown in Table 6.

While $25 \%$ of the students believed that the conceptualization phase contributed very much or much to the learning, $62.5 \%$ believed that the instruction sheets were very helpful or helpful. Moreover, $62.5 \%$ indicated that they learned very much or much when they collaborated with other students, and 50\% when they asked their teacher for help. Finally, 
Table 6

Learning effect of concept-based approach in class 4 (in percent)

\begin{tabular}{lccccc}
\hline & $N$ & $\begin{array}{r}\text { Learned } \\
\text { very much }\end{array}$ & $\begin{array}{r}\text { Learned } \\
\text { much }\end{array}$ & $\begin{array}{r}\text { Learned } \\
\text { little }\end{array}$ & $\begin{array}{r}\text { Learned } \\
\text { very little }\end{array}$ \\
\hline Conceptualization phase (3 P's) & 8 & 12.5 & 12.5 & 75.0 & 0.0 \\
Construction phase: Instruction sheets & 8 & 12.5 & 50.0 & 25.0 & 12.5 \\
Construction phase: Student collaboration & 8 & 25.0 & 37.5 & 12.5 & 25.0 \\
Construction phase: Ask teacher for help & 8 & 0.0 & 50.0 & 25.0 & 25.0 \\
Dialogue phase: Discuss with teacher & 8 & 25.0 & 12.5 & 50.0 & 12.5 \\
\hline
\end{tabular}

the dialogue phase was less successful since only $37.5 \%$ think that this phase contributed to learning.

\subsection{Global Analysis: Putting the Classes Together}

A global analysis of the data collected refers to classes that were evaluated on the basis of common variables. Three classes $(1,2$, and 3 ) are concerned with the variables connected to the learning potentiality and motivational power, as well as conceptualization and construction phase $(N=89)$. Hence, class 4 is not considered in the following analysis.

Table 7 shows the distribution of the data across the range of values of the four-point scale. This indicates that more than $80.0 \%$ of the students believed that the learning potentiality of the approach is very high or high, and almost $90 \%$ think that the motivational power is high or very high.

Table 7 also indicates that more than $71 \%$ believed that they learned very much or much in the conceptualization phase and $75.3 \%$ think that instruction sheets contributed much or very much to the learning process. Finally, Table 7 indicates that about $90 \%$ of the students collaborated very much or much with other students, in stark contrast to students who asked their teacher for assistance (about 33\%). It seems that collaboration with other students was very stimulating, in stark contrast to asking the teacher for help.

Table 7

Global analysis of class 1, 2, and 3 (in percent)

\begin{tabular}{lccccc}
\hline & $N$ & $\begin{array}{r}\text { Learned } \\
\text { very much }\end{array}$ & $\begin{array}{r}\text { Learned } \\
\text { much }\end{array}$ & $\begin{array}{c}\text { Learned } \\
\text { little }\end{array}$ & $\begin{array}{r}\text { Learned } \\
\text { very little }\end{array}$ \\
\hline Learning potentiality & 89 & 41.6 & 41.6 & 11.2 & 5.6 \\
Motivational power & 89 & 50.6 & 39.3 & 6.7 & 3.4 \\
Conceptualization phase (3 P's) & 89 & 15.7 & 56.2 & 22.5 & 5.6 \\
Construction phase: Instruction sheets & 89 & 20.2 & 55.1 & 18.0 & 6.7 \\
Construction phase: Student collaboration & 89 & 61.8 & 28.1 & 10.1 & 0.0 \\
Construction phase: Ask teacher for help & 89 & 9.0 & 24.7 & 62.9 & 3.4 \\
\hline
\end{tabular}


Table 8

Differences between class 1, 2, and 3 (in percent)

\begin{tabular}{lccc}
\hline & Class 1 & Class 2 & Class 3 \\
\hline Learning potentiality & 56.3 & 91.3 & 80.0 \\
Motivational power & 62.5 & 98.2 & 86.7 \\
Conceptualization phase (3 P's) & 37.6 & 84.5 & 60.0 \\
Construction phase: Instruction sheets & 68.7 & 84.5 & 46.7 \\
Construction phase: Student collaboration & 75.0 & 94.8 & 86.7 \\
Construction phase: Ask teacher for help & 81.3 & 6.9 & 86.6 \\
\hline
\end{tabular}

\subsection{Differences between Class 1, 2, and 3}

A careful analysis shows that there are important differences between class 1, 2 and 3 (Table 8). The analysis considers only two categories across the range of values of the four-point scale: "Learned Very Much" and "Learned Much". While class 2 and class 3 achieved relatively higher percentages with regard to the variables "learning potentiality" and "motivational power" than class 1 , it appears that the most important differences between the three classes are linked to the variables "conceptualization", "instruction sheet", and "ask teacher for help". The percentage of class 2 is much higher than the one achieved for class 1 and class 3, except for the variable "ask teacher for help". Indeed, the percentage achieved for class 2 with respect to "ask teacher for help" is extremely low (6.9\%) compared to $81.3 \%$ (class 1 ) and $76.4 \%$ (class 3 ). Reasonable explanations of these differences need to involve theoretical considerations, and knowledge from other data sources. Some explanations could likely be the following:

- Teachers from different schools use different pedagogies and ways of teaching. It is possible that independent learning is more emphasized in class 2 than in class 1 and 3.

- The topics taught in the classes were different, including their level of difficulty. While class 1 and 3 taught very similar topics (Web design), class 2 taught "designing audio files", which are very different. This may have affected the way students asked their teacher for assistance and the amount of help they needed to solve problems.

- It seems that class 2 took more advantage of the conceptualization phase and instruction sheets than class 1 and 3 as the results clearly reveal. This may have enabled the students to become less dependent on the teacher's assistance.

\subsection{Supplementary Evaluations of the Approach}

In addition to students' views, the work collected data by means of formal and informal discussions with trainee teachers, observations of teaching practice, and analysis of project reports that the teachers delivered at the end of the teaching practice. To facilitate the analysis of their views, the evaluation criteria were closely aligned with those of 
the students by means of survey questionnaires. A detailed analysis of the results will be described in a future paper. A summary of the evaluations shows the following results:

- Trainee teachers indicated that their students were satisfied with the conceptualization and construction phase of the approach. They think that the three P's were useful for understanding and grasping informatics concepts.

- Trainee teachers reported that they did not attach much importance to the dialogue phase. Instead, they adopted a more pragmatic approach to communication with the students as discussion and dialogue were spread out over the duration of the teaching sessions.

- They also reported that the planning of the pedagogical approach was demanding in terms of efforts and time. They experienced that the design of intrinsically motivating examples and associated software concepts required more efforts than originally anticipated.

- In addition, trainee teachers experienced that a number of students were far weaker than might be expected in secondary education. They reported that it was not always possible to let those students work independently without interfering and stimulating them to take part in the problem solving process.

- Trainee teachers pointed out that factors such as self-confidence, motivation, and knowledge background both in computing and pedagogy played an important role in their teaching. They also mentioned that the availability of study material and teaching resources from previous studies were an important factor that helped them to consistently use the pedagogical approach in their teaching practice.

- Finally, trainee teachers believed that the concept-based pedagogical approach has the potential for improving the students' learning of informatics if the approach is applied consistently and continually over a long period of time and some internal and external conditions are fulfilled.

\section{Discussion}

In this section, a summary of findings and implications for the teaching and learning of school informatics in secondary schools is presented. The limitations of the work are discussed as well. The findings help to answer the two research questions:

1. How do students perceive the concept-based pedagogical approach in their learning of school informatics?

2. What are the implications for the teaching and learning of school informatics in secondary education?

\subsection{Summary of Findings}

The students' perceptions of the concept-based approach can be summarized as follows:

- Learning potentiality. Most students from three classes $(N=89)$ think that the concept-based pedagogical approach is potentially very well suited to the learning of school informatics. 
- Motivational power. The approach is potentially very motivating for most students as the evaluation of three classes clearly reveal $(N=89)$.

- Conceptualization phase (3 P's). More than the majority of the students agreed that they learned very much or much in this phase, which aims at providing a conceptual understanding of informatics.

- Instruction sheet. More than the majority also agreed that instruction sheets provided help to the problem solving process in the construction phase of the approach.

- Student collaboration. Most students reported that collaborative activities with fellow students were helpful, even if the theoretical framework does not attribute a key role to student collaboration in the construction phase.

- Teacher help. The findings indicate that about 33\% of the students considered that asking their teacher for assistance is helpful. Hence, more than the majority felt that they could work on their own without being dependent on the teacher.

- Dialogue phase. Only a limited number of students $(N=24)$ evaluated this phase. However, the results indicate that this phase was given insufficient consideration.

- Differences between classes. The findings indicate that there are some important differences between class 2, on the one hand, and class 1 and 3, on the other hand, with regard to the conceptualization and construction phase.

\subsection{Implications for the Learning of School Informatics}

From the evaluation results the following implications for the teaching and learning of school informatics can be drawn for five major organizing themes:

- conceptual understanding,

- learning resources,

- learning activities,

- collaborative learning,

- overall learning approach to school informatics.

These five themes can play an important role and it would be helpful to take them into account explicitly when teaching and learning school informatics.

\subsubsection{Conceptual Understanding}

From the point of view of the cognitive learning theory, the basic idea of the pedagogical approach to school informatics is underpinned by an understanding of informatics concepts. This supports the view that, though informatics is - among other orientations - considered as a technical discipline (Trede and Sutnen, 2008; Trede, 2007), it cannot be learned solely through interaction with a computer, trial-error working, imitation, and approximations. Clearly, the learning of informatics must be based on concepts and principles (Hadjerrouit, 2009; Schwill, 1997; Stechert and Schubert, 2007). In line with this idea, the conceptualization phase of the pedagogical approach aims at providing an adequate support for understanding informatics concepts.

The findings show that conceptual understanding is a critical factor of success in teaching and learning informatics. But, the conceptualization phase in itself is not suf- 
ficient, unless informatics concepts are taught and learned according to pedagogical principles. There are many reasons that can hinder conceptual understanding.

First, it is not an easy task for teachers to lay the groundwork for teaching informatics concepts through the three P's. This phase is time consuming and demanding in terms of efforts for novice trainee teachers. Finding relevant situated examples, presenting a procedural overview, and using understanding tools for explaining informatics concepts, are challenging tasks and require more conceptual efforts than traditional informatics teaching.

Second, the rapidly changing nature of software and the complexity of the features and functionality of software tools make it difficult to identify informatics concepts, and how to present them to the students. Indeed, it is almost impossible for teachers to know all the specific features of all the software tools that they use, because software is continually being developed and improved (Hammond, 2004; Webb, 2002). The advantage of the pedagogical approach presented in this paper is that teachers do not need to know all the features of all the software as long as they know how to find out about these features, and specify situated examples using informatics concepts.

For the students, the understanding of informatics concepts requires cognitive efforts rather than reproducing information about buttons, menu commands, and dialogue boxes. The role of the teacher is to help the students to learn by conceptual understanding, not by approximations, memorizations, and imitations. The conceptualization phase would not have the desired effect if students do not learn informatics concepts that help them to consistently organize the information they know about software and computers.

An important implication that follows from these considerations is that schools need to emphasize qualifications that enable teachers to identify informatics concepts using multiple forms of representations, especially visualisations. Teachers also need to identify suitable contexts for the application of the concepts using situated examples. As a result, this work suggests that more efforts be invested and new ways of presenting informatics concepts to the students be explored.

\subsubsection{Learning Resources}

Instruction sheets can be considered as the most important learning resource of the concept-based pedagogical approach. These are designed in analogy to the three P's, that is to say Principles, Problem, and Procedural overview. Analogical thinking is important to learning according to the research literature (Wu et al., 2004). The question is whether instruction sheets as presented in this paper can to a certain degree replace or be used as supplement to traditional resources that do not require conceptualizations.

The findings of this work indicate that instruction sheets can to a certain degree provide conceptual understanding. Consequently, they can help students to solve informatics problems successfully, because, in contrast to textbooks, they are based on principles and conceptualizations.

However, if instruction sheets can potentially contribute to learning, they are in themselves not sufficient, unless they are well-designed according to pedagogical criteria. Clearly, a number of difficulties are associated with instruction sheets. 
First, the design of well-structured instruction sheets requires conceptual efforts as it is not easy to find an appropriate balance between information that is supposed to explain how students should perform the steps specified in the procedural overview, on the one hand, and the menus, buttons, and dialogue boxes, on the other hand. In addition, instruction sheets should be subject for reuse and adaptation for similar problems. Clearly, their design is demanding in terms of efforts for novice trainee teachers.

Second, it cannot be expected that students without sufficient computer skills can use instruction sheets, since they need to understand technical aspects of computing such as dialogue boxes and menu commands. Without sufficient background, they would not be able to work on their own solving software problems using instruction sheets. Weak students would become dependent on the teacher's help. Moreover, while some knowledge background in computing is necessary, it is not sufficient for learning to use instruction sheets in order to become less dependent on teacher assistance. Students' needs, self-confidence, motivation, and maturity are equally important factors of success (Hadjerrouit, 2008). It follows that the concept-based pedagogical approach is not recommended in lower secondary schools due to the low level of students' digital competency and lack of maturity in managing their own learning process.

\subsubsection{Learning Activities}

From a constructivist point of view, the construction phase is important, because it requires active involvement in problem solving, such as building user-friendly data models using Microsoft Access or designing Web-based applications using Dreamweaver and Adobe Flash.

According to Brinda (2007), connecting different pieces of information contributes to learning. In line with this idea, learning activities in the construction phase are supposed to connect three elements: Instruction sheets, the software tool to be used, and the problem to be solved. This, in turn, can enhance the quality of informatics conceptualizations.

However, designing learning activities according to the concept-based pedagogical approach is demanding in terms of intellectual efforts for the teacher, since a number of principles must be fulfilled. First, instruction sheets should be designed in such a way that they give a generalized explanation on how to solve a specific type of problem, but not specify how to solve the problem that is handed out by the teacher. Then, the concepts to be used to solve the problem should be integrated into the instruction sheet so that they can guide the student. Finally, an important issue of designing learning activities is not to mix the problem with the instruction sheet. A number of implications for the design of learning activities follow from these considerations for teachers.

Besides the fact that it is a challenging task to identify informatics concepts as mentioned in the above section, it is also difficult to design instruction sheets based on conceptualizations. Moreover, a factor that may inhibit the problem solving process is the software being used. The type and the degree of complexity of the software could indeed be a serious obstacle for using the concepts, the way students perform their tasks, and how they interpret the concepts presented in the conceptualization phase. This is in line with previous research that has shown that different types of software can have different learning effects on students (Cox and Marshall, 2007). The opportunities provided 
by a range of software could only be taken by students if the teachers themselves know enough about the software in order to be able to design learning activities. For instance, the teaching of a software tool such as Microsoft Access, will have limited effect if the teacher has not understood the opportunities that the software provides, such as the concepts and techniques of data representation and modeling, metaphors and capabilities of type of application. Clearly, without sufficient knowledge of the software being used, it could be difficult for teachers to apply the concept-based pedagogical approach.

\subsubsection{Collaborative Learning}

The findings of this work point out that collaborative learning is still more important to the students than the individual acquisition of skills. This confirms the evidence found in the research literature that learning informatics is an inherently social activity as good solutions are developed not in isolation; instead they involve interaction with other people (McDougall and Boyle, 2004).

The implication of this finding is that the learning of informatics should promote collaborative work, giving the students a sense of how good solutions can be performed in collaboration with fellow students and teachers. Collaborative learning can be involved at three different levels. First, it can be useful to let students work together in the construction phase. But, as Jedoskog and Nissen (2004) stated, there is a risk to hand over much responsibility to the students themselves, because the process of transferring responsibility to the students can end in a situation where technicalities of the software receive more attention than conceptual understanding of informatics.

Second, collaborative activities with the teacher in the construction phase might be of great value for the learning process. Indeed, weaker students may ask the teacher for assistance. The teacher must then provide appropriate help. In this situation, the teacher must act as a facilitator of learning rather as a transmitter of knowledge.

Third, collaborative learning is equally important in the third phase of the conceptbased approach. However, the findings indicate that the dialogue phase was not integrated into the learning process as might be expected. As a result, this phase did not play a key role, since students did not view the lack of discussion at this level as a significant obstacle for the learning process. However, from a pedagogical point of view, the dialogue phase is potentially very important for consolidating the students' understanding of informatics concepts. Hence, it can be useful to explicitly integrate the dialogue phase into the learning process to promote enhanced conceptual understanding.

\subsubsection{Overall Learning Strategy}

Generally speaking, the findings of this work confirm the idea that a pedagogically sound model of teaching based on conceptualizations, principles, organization of information has the potential for improving the learning of school informatics.

However, teachers need to be aware of the limitations of the approach. Principles, situated examples, and instruction sheets are highly important but not sufficient to help students progress beyond the novice stage of learning based on approximations, memorizations, and imitation to a higher stage of learning based on conceptualizations. To 
apply this approach successfully, it is important that students possess sufficient computer skills. Moreover, the approach must be adapted to the students' needs and motivations. Then, the approach requires students' self-confidence and maturity, because the use of instruction sheets is demanding in terms of conceptual efforts. Finally, it is important to let students help each other during the construction phase instead of being dependent on the teacher's assistance. Clearly, if autonomy in learning is important, it is not sufficient due to the importance of collaborative learning and interactions with the teacher and fellow students. Hence, the approach needs to be combined with a pedagogically sound model of collaborative learning, which includes both student-student collaborations and teacherstudents interactions. Collaborative learning is effective only if teachers not only convey subject knowledge to the students, but also act as facilitators of learning. In addition, student collaboration is particularly useful when the more competent students help the ones who face difficulties in performing their tasks.

\subsubsection{Limitations of the Work}

The results of this work cannot be generalized, because of various factors such as a single experiment of limited duration, the small sample size $(N=99)$, the small number of classes $(N=4)$, four different teachers, and three different topics.

In addition, it is questionable whether all students were able to understand and reasonably answer all the themes and questions of the survey questionnaire. Hence, an important concern of this work is the reliability and validity of the method used to collect students' perceptions of the concept-based approach.

Given these considerations, it is expected that new cycles of evaluations of the pedagogical approach in future studies are warranted to generalize the findings of the present work. In addition, the methods used for collecting empirical data should be assessed and refined to ensure their validity and reliability, and completed with supplementary, both quantitative and qualitative, methods.

\section{Conclusions and Future Work}

The findings of this work indicate that the concept-based pedagogical approach has the potential to enhance the learning of informatics as a subject in secondary schools. Even if it is impossible to draw general conclusions from the work presented in this article, it can be ascertained that the students expressed their satisfaction with the concept-based pedagogical approach to school informatics in many ways, despite the fact that they did not reject traditional teaching methods. First, they felt that the concept-based approach is potentially powerful with regard to its learning contribution. Second, they think that the approach is intrinsically motivating to be used in classroom. Third, they indicated that instruction sheets can effectively be used for problem solving. Finally, they expressed that collaborative learning is still important to school informatics.

However, the results of this work cannot be generalized. There is a need for more evidence to support the conclusions. In this regard, it may be necessary in future work 
to ask the students about what they really learned about informatics in terms of skills gained, and what they really are able to do as a result of the concept-based approach to school informatics.

Yet, radical pedagogical changes in school informatics are difficult to achieve within teaching experiments of limited duration, because working simultaneously as teacher (using a new pedagogical approach) and researcher (performing research work on the approach), are challenging tasks for many trainee teachers to deal with in classroom (Cochran-Smith, 2005; Postholm, 2006). Nevertheless, pedagogical changes are possible under some conditions. First, to successfully apply the concept-based pedagogical approach, trainee teachers must be motivated and convinced of the need for pedagogical change in informatics teaching and how change can be incorporated into their teaching practice (Kalogiannakis, 2009). Second, trainee teachers should possess sufficient background in informatics and pedagogical knowledge in order to be able to apply the approach. Third, trainee teachers should rely on the main principles of the approach when they teach school informatics. Fourth, they should motivate students, enrich learning, stimulate conceptual reasoning, foster students' independence, autonomy and ownership, and collaborative learning as well (Atjonen, 2006; Mooij, 2009). Fifth, trainee teachers should critically reflect on their own teaching on the basis of the principles discussed in this paper, since the way they teach will influence the ways they use the concept-based approach (Barak, 2006). If these conditions are fulfilled, it can then be expected that the approach will have some impacts on the students' learning of informatics.

However, to exploit the full potential of new pedagogical approaches like the one presented in this paper there is a need for establishing school informatics as a compulsory subject in secondary schools. This task requires the stakeholders involved in teacher education and secondary schools to be initiated into the specifics of school informatics beyond the strict use of IT as a tool. This task requires long-term efforts. To be successful, it is of paramount importance to initiate a debate on the need for a new vision of informatics as a subject in its own right.

In future work, the author intends to continue to study school informatics not as an isolated parameter or a software tool for other subjects, but as an integrated variable based on conceptualizations and principles. The author also intends to gather new data in future studies in order to generalize the findings of this work, as well as to obtain a more in-depth theoretical and practical understanding of the process of introducing a new pedagogical approach to school informatics. Finally, it is also important to investigate the students' learning in terms of knowledge and skills gained as a result of the concept-based approach to informatics.

\section{References}

ACM (2003). ACM/CSTA K-12 CS Model Curriculum (2003).

http: / / www. csta.acm.org/Curriculum/sub/Currfiles/K-12ModelCurr2ndEd.pdf Atjonen, P. (2006). Finnish teachers and pupils as users of ICT. Informatics in Education, 5(2), 167-182.

Barak, M. (2006). Instructional principles for fostering learning with ICT: Teachers' perspectives as learners and instructors. Education and Information Technologies, 11, 121-135. 
Belland, B.R. (2009). Using the theory of habitus to move beyond the study of barriers to technology integration. Computers \& Education, 52, 353-364.

Brinda, T. (2007). Development of the exercise culture in informatics. In: Proceedings of IFIP Conference on Informatics, Mathematics and ICT: A Golden Triangle, June 27-29, Boston, USA.

Bruillard, E. (2004). From the didactics of computer science towards the didactics of instrumental activities with ICT. In: Second Greek Conference on Didactics of Informatics, Volos, January 2004.

Bruner, J. (1990). Acts of Meaning. Harvard University Press, Cambridge, MA.

Cochran-Smith, M. (2005). Teacher educators as researchers: Multiple perspectives. Teacher and Teacher Education, 21, 219-225.

Cox, M.J., Marschall, G. (2007). Effects of ICT: Do we know what we should know? Education and Information Technologies, 12, 59-70.

Dagdilelis, V., Satratzemi, M., Evangelidis, G. (2004). Introducing secondary education students to algorithms and programming. Education and Information Technologies, 9(2), 159-173.

Duffy, T.M., Lowyck, J., Jonassen, D.H. (1993). Designing Environments for Constructive Learning. SpringerVerlag, Berlin.

Freischlad, S., Stechert, P. (2008): Discovery learning about informatics systems. In: Wheeler, S., Brown, D., Kassam, A. (Eds.), Proceedings of Joint Open and Working IFIP conference on ICT and Learning for the Net Generation, July 7-10, Kuala Lumpur (Malaysia), 2008.

Gagne, E., Yekovich, C., Yekovisch, F. (1993). The Cognitive Psychology of School Learning, 2nd ed. HarperCollins, New York.

Haberman, B. (2004). High-school students' attitudes regarding procedural abstraction. Education and Information Technologies, 9(2), 131-145.

Hadjerrouit, S. (2009). Didactics of ICT in secondary education: Conceptual issues and practical perspectives. In: Issues in Informing Science and Information Technology, Vol. 6, 153-178.

Hadjerrouit, S. (2008). Using a learner-centered approach to teach ICT in secondary schools: An exploratory study. In: Issues in Informing Science and Information Technology, Vol. 5, 233-259.

Hammond, M. (2004). The peculiarities of teaching information and communication technology as a subject: A study of trainee and new ICT teachers in secondary schools. Technology, Pedagogy and Education, 13(1), $29-42$.

Herskin, B. (2004). IT-undervisning - med brugeren i centrum (in Danish, IT training - The user in the centre). Nyt Teknisk Forlag, København.

Hromkovic, J. (2006). Contributing to general education by teaching informatics. In: Proc. ISSEP'2006, Informatics Education - The Bridge between Using and Understanding Computers, Lecture Notes in Computer Science, Vol. 4426. Springer-Verlag, 25-37.

Jedeskog, G., Nissen, J. (2004). ICT in the classroom: Is doing more important than knowing? Education and Information Technologies, 9(1), 37-45.

Kalogiannakis, M. (2009). Training with ICT for ICT from the trainee's perspective. A local ICT teacher training experience. Education and Information Technologies, 2 (in press).

Karagiorgi, Y., Symeou, L. (2005). Translating constructivism into instructional design: Potential and limitations. Educational Technology and Society, 8(1), 17-27.

Lin, B., Hsieh, C. (2001). Web-based teaching and learner control: A research review. Computers and Education, 37(3-4), 377-386.

Mayes, J.T., Fowler, C.J. (1999). Learning technology and usability: A framework for understanding courseware. Interacting with Computers, 11(5), 485-497.

Micheuz, P. (2008). Some findings on informatics education in Austrian academic secondary schools. Informatics in Education, 7(2), 221-236.

McDougall, A., Boyle, M. (2004). Students strategies for learning computer programming: Implications for pedagogy in informatics. Education and Information Technologies, 9(2), 109-116.

Mooij, T. (2009). Education and ICT-based self-regulation in learning: Theory, design, and implementation. Education and Information Technologies, 14, 3-27.

Minaidi, A., Hlapanis, G.H. (2005). Pedagogical obstacles in teacher training in information and communication technology. Technology, Pedagogy and Education, 14(2), 241-254.

New National Curriculum in Norway (2006). Knowledge promotion.

http://www.regjeringen.no/en/dep/kd/Selected-topics/compulsoryeducation/Knowledge-Promotion.html?id=1411 
Nishida, T. et al. (2009). A CS unplugged design pattern. In: Proceedings of the 40th ACM technical symposium on Computer science education, (SIGCSE'09), March 3-7, 2009, Chattanooga, Tennessee, USA, 231-235. Piaget, J. (1972). The Psychology of the Child. Basic Books, New York.

Postholm, M.B. (2006). The teacher's role when pupils work on task using ICT in project work. Educational Research, 48(2), 155-175.

Steffe, L.P., Gale, J. (Eds.) (1995). Constructivism in Education. Lawrence Erlbaum Associates, New Jersey.

Schwill, A. (1997). Computer science education based on fundamental ideas. In: Proceedings of the IFIP TC3 WG3.1/3.5 Joint Working Conference on Information Technology: Supporting Change through Teacher Education, 285-291.

Stechert, P. (2008). Systematic exploration of informatics systems. In: Kendall, M. and Samways, B. (Eds.), IFIP International Federation for Information Processing: Learning to Live in the Knowledge Society, Vol. 281. Springer, Boston, 359-360.

Stechert, P., Schubert, S. (2007). A strategy to structure the learning process towards under-standing of informatics systems. In: Benzie, D., Iding, M. (Eds.), Proceedings of IFIP Conference on Informatics, Mathematics and ICT: A Golden Triangle, June 27-29, Boston, USA.

Trede, M., Sutnen, E. (2008). Three traditions of computing: What educators should know. Computer Science Education, 18(3), 153-170.

Trede, M. (2007). Know your Discipline: Teaching the philosophy of computer science. Journal of Information Technology Education, 6, 105-122.

UNESCO (2002). Information and communication technology in education: A curriculum for schools and programme of teacher development.

http: / / unesdoc. unesco.org/images/0012/001295/129538e.pdf

Vygotsky, L.S. (1978): Mind and Society: The Development of Higher Mental Processes. Harvard University Press, Cambridge, MA.

Webb, M.E. (2002). Pedagogical reasoning: Issues and solutions for the teaching and learning of ICT in secondary schools. Education and Information Technologies, 7(3), 237-255.

Wenger, E. (1998). Communities of practice: Learning, Meaning, and Identity. Pinter, London.

Woollard, J. (2005). The implication of the pedagogic metaphor for teacher education in computing. Technology, Pedagogy and Education, 14(2), 189-204.

Wu, C-C., Lee, G.C., Lai, H.-K. (2004). Using concept maps to aid analysis of concept presentation in high school computer textbooks. Education and Information Technologies, 9(2), 185-197.

S. Hadjerrouit received the MS and PhD degrees in software engineering and artificial intelligence from the Technical University of Berlin (Germany), in 1985 and 1992, respectively. He joined University of Agder, Kristiansand (Norway) in 1991. He is currently an associate professor of computer science at the Faculty of Technology and Sciences. He has been in the teaching profession for 27 years. He has extensive experience in teaching object-oriented programming, software development, databases, and didactics of informatics. His research interests include object-oriented software development, computer science and software engineering education, didactics of informatics, ICT in mathematics education, and development of e-learning systems. Hadjerrouit has published over 70 papers in international journals and conference proceedings. 


\section{Mokyklinės informatikos mokymas ir mokymasis: konceptualusis pedagoginis metodas}

\section{Said HADJERROUIT}

Visame pasaulyje informatikos studijos yra įsitvirtinusios aukštajame moksle, tačiau vidurinio lavinimo mokyklose to nèra (išimtis - kelios valstybès). Apskritai, mokyklose dèstomas ne informatikos dalykas (su jam būdingais metodais, sąvokomis ir principais), o supažindinama su tam tikra programine ịranga, siekiant suteikti studentams pakankamai igūdžių. Išanalizavus dabartinę situaciją buvo nustatyta, kad tikrieji mokytojų ir mokiniu informatikos gebejjimai viduriniame lavinime yra daug silpnesni nei buvo galima tikètis. Šiame straipsnyje siūloma mokyklinès informatikos koncepcija, pagrịsta konceptualiuoju pedagoginiu metodu. Siekiama suteikti mokiniams gilesnį suvokimą apie informatiką kaip mokslo objektą. Straipsnyje nagrinėjamos ir mokinių nuomonès apie konceptualiojo pedagoginio metodo indèli, mokymo reikšmę ir informatikos mokymąsi vidurinèje mokykloje. 